\title{
OBITUARY
}

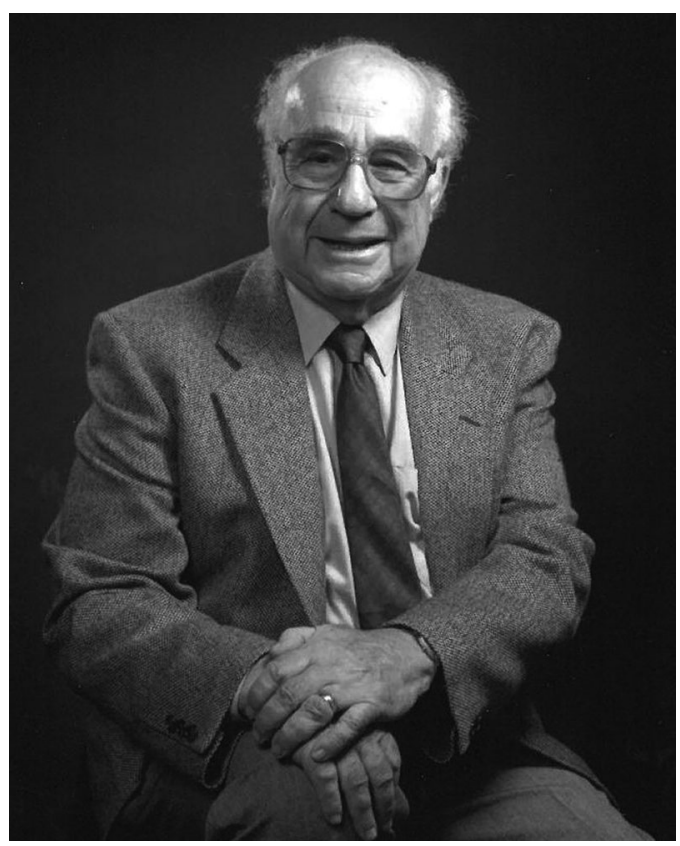

A studio portrait of John Gumperz. (Photo courtesy of public domain)

\section{John Joseph Gumperz (1922-2013)}

John Joseph Gumperz, one of the founding fathers of sociolinguistics and modern linguistic anthropology, died on March 29, 2013, in Santa Barbara, California. He was born Hans-Josef Gumperz on January 9, 1922, in Hattingen in the Ruhr, Germany, where his Jewish family owned a soap factory. When the Nazi party came to power, he was barred from high school, and his family sent him to Italy for schooling in 1935. After Kristallnacht in 1938, it was clear to the family that it was time to leave Europe, and so in 1939 they left for Cincinnati. John enrolled for a bachelor's degree in chemistry at the University of Cincinnati, but his studies were interrupted in 1943 when he was sent back to Germany as a translator and interrogator for the occupying U.S. forces. He finished his degree in 1947, then moved to the University of Michigan for graduate studies in chemistry. As it happened, the Linguistic Institutes (summer schools) of the Linguistic Society of America were held annually in Michigan from 1945 to 1950, mostly under the direction of Hans Kurath, the dialectologist who initiated the Linguistic Atlas of the United States. Seeing the possibility of exploiting his multilingual background and interests, Gumperz soon switched from chemistry to linguistics. His dissertation work was on third-generation bilingual speakers of Swabian dialects in Washtenaw County, Michigan, where he discovered three distinct dialects that had evolved focused on distinct Lutheran synods. His doctorate was awarded in 1954.

By this time, Gumperz had moved to a post in modern languages at Cornell, where he soon joined a Ford Foundation project fostering interdisciplinary development studies in India, combining anthropology, linguistics, sociology, political science, and economics. The project had a base at Deccan College, Pune, where in 1954-56 Gumperz came into contact with Charles Ferguson and William Bright. He focused on the dialects of Hindi in the village of Khalapur in the far north of Uttar Pradesh. As in his PhD work, he found that dialects cannot be explained mechanically in terms of barriers to communication; instead, they require a consideration of social motivations. His two years in India convinced him of the importance of combining linguistics with a study of social structure and process. He went on to coedit a volume on linguistic diversity in South Asia (Ferguson and Gumperz 1960), which in retrospect can be viewed as the first major collection in the new field of sociolinguistics. ${ }^{1}$

By 1956, Gumperz had moved to the University of California at Berkeley, initially as a Hindi instructor. There he was soon surrounded by many scholars interested in the social foundations of language, including Susan Ervin-Tripp, Erving Goffman, John Searle, Dell Hymes, Dan Slobin, and the Indianists Murray Emeneau, Gerald Berreman, and Frits Staal. Gumperz was an eclectic scholar who forged theory from many ideas, and he benefited greatly from this rich milieu. In particular, he found his own training and experiences nicely complemented by Dell Hymes's background in Amerindian linguistics and folklore and his wide knowledge of ethnographic linguistics. Together they edited a special issue of the American Anthropologist (Gumperz and Hymes 1964) on "The Ethnography of Communication," which essentially crystalized the ethnography of speaking. Influential to this and other early publications was the Sociolinguistics Committee of the Social Science Research Council, initiated in 1963, in which Gumperz played a key role, forming small working "Gumperz groups." The committee at one time or another included most of the foundational figures in anthropological linguistics and sociolinguistics; of all of these, Gumperz was perhaps the most able to absorb new developments in many disciplines and explore their potential implications for sociolinguistics. 
When Hymes left Berkeley in 1965, Gumperz inherited his position in the Department of Anthropology. But their collaboration continued with the edited volume Directions in Sociolinguistics (1972), which served as a textbook for the new field. That same year Gumperz's first wife, Ellen née McDonald, took her own life, leaving him with two small children. He was fortunate to find a new partner in Jenny Cook, a postdoc from Basil Bernstein's department in London, who became a coauthor and coeditor of much of his later work, contributing her British sociological expertise to their joint analyses.

Gumperz's work had taken a more fine-grained interactional focus in the late 1960s and early 1970s, starting with his investigation with Jan-Petter Blom of the contrastive uses of standard and local dialects in Norway (Blom and Gumperz 1972). This interactional perspective dovetailed with the evolving Berkeley environment, where an emphasis on inferential processes in language use was emerging in the work of Paul Grice, John Searle, George and Robin Lakoff, Charles Fillmore, Paul Kay, Brent Berlin, Susan Ervin-Tripp, Dan Slobin, and others. The establishment of the Language Behavior Research Lab at Berkeley provided a haven where Gumperz and a talented cohort of students and collaborators could explore these issues. These ideas gelled in the books Discourse Strategies and Language and Social Identity, both appearing in 1982 (Gumperz 1982a, 1982b).

A BBC film (Cross-Talk [Twitchin and Thompson 1979]) produced with an accompanying booklet (Gumperz et al. 1979) illustrated the inadvertent misunderstandings due to dialect and accent differences and established a compelling case for the importance of subtle conversational inferences, thus promising a new advocacy role for sociolinguistics. The idea that possibly well-intentioned but powerful gatekeepers could make life-changing decisions on the basis of fleeting misunderstandings has proved one of Gumperz's most enduring contributions. He went on to develop these themes in his last works, maintaining that sociolinguistics led the way toward political engagement in modern anthropological linguistics (Gumperz and CookGumperz 2008).

Gumperz retired from Berkeley in 1991 and moved to UC Santa Barbara, where he joined the Language, Interaction, and Social Organization unit.

Gumperz is best known for his specific brand of "interactional sociolinguistics," but his work ranged over major themes in the relation of language to social structure, and it may be useful to sketch how the different strands fit together. The root of much of his thought can be found in his early work in India. In an early article (Gumperz 1958), using his new Indian data, he confronted the idea in traditional dialectology that dialects directly reflect frequency of communication. Quoting Leonard Bloomfield (1933:46), who had sketched a kind of proto-network analysis and held that "the most important differences of speech within a community are due to differences in the density of communication,"
Gumperz showed this to be false: his Indian village with 31 castes had just four dialects. People of different castes who spent most of their lives working together might never acquire each other's dialects. Gumperz distinguished pure Bloomfieldian connectedness from network ties with specific affective properties: it was only friendship networks that transmitted dialect forms. Gumperz can be credited with introducing the promise of network analysis to sociolinguistics and with pointing out that friendship ties are the dialect superconductors.

The division between work ties, on the one hand, and friendship-kinship ties, on the other hand, was developed further in a celebrated article that did much to spur later work on language contact (Gumperz and Wilson 1971). It explored the ways in which unrelated languages in daily contact through work ties converge in their underlying structure but retain distinct formal diacritics to mark sociolinguistic distance. Work ties also played a crucial role in Gumperz's later writing on bureaucracy in complex societies, wherein gatekeepers control access to resources while dialect differences undermine the rhetorical effectiveness of plaintiffs.

Gumperz was simultaneously exploring the other half of the distinction - namely, friendship and kinship ties. Through such ties, there is transmission of the full linguistic repertoire - not only dialect properties but also languages involved in code-switching and distinctive discourse styles. Gumperz was intrigued not so much by situational code switching but by what he called metaphorical switching: the rapid mid-sentence switching between fluent bilinguals that serves to index subtle allusions or trigger complex inferences. Gumperz's initial foray here (Blom and Gumperz 1972) concerned switching between two dialects or registers of the same language in Norway, a kind of language switching that has been the focus of much later work investigating the nature of the metasystem that makes it possible.

The study of friendship networks prepared the way for another phase of Gumperz's investigation. He had found it difficult to nail down exactly the fleeting meanings or inferences generated by code switching. Here, drawing on Harold Garfinkel's insight that breaches of social norms reveal them (Gumperz 2001), Gumperz focused on where communication breaks down: inevitably, but without awareness, we deploy the same inferential triggers we use in our friendship networks to generate subtle allusions outside those networks, where our implied messages may be lost or misinterpreted. This line of work led to Crosstalk (Gumperz et al. 1979; Twitchin and Thompson 1979) and to the discovery of "contextualization cues." The underlying concept here had already been introduced to anthropologists by Gregory Bateson's (1956) notion of the "metamessage," as when a puppy snarls while simultaneously indicating with his body that "this is play." Gumperz's specialization of the idea was that an utterance could carry with it instructions about the context within which it should be understood. His work 
suggested that in English it is prosody in particular that carries this metasignal (in other languages, particles or marked constructions might do the same job). It is a powerful idea with a number of intriguing consequences (Levinson 1997), but Gumperz was particularly interested in the potential for miscommunication that occurs when these metasignals are used outside the networks in which they are effortlessly decoded. He focused on gatekeepers in bureaucratic societies because in such job or welfare interviews a brief meeting can affect individuals' life chances in fundamental wayshence the promise of a sociolinguistics that might better the world.

Gumperz had now, with this focus on contextual meaning in discourse, introduced a new hermeneutic turn in sociolinguistics, downplayed in the variationist sociolinguistics of William Labov and followers, wherein sociolinguistic variables are mere associationist markers, not rich inferential triggers for the meta-analysis of communicative content. This hermeneutic turn made it possible to think about a relativity of interpretations, ideas explored in a WennerGren conference, "Rethinking Linguistic Relativity," and its resulting published volume (Gumperz and Levinson 1996). Gumperz's overall approach was unique in that it combined a dialectology compatible with standard variationist sociolinguistics with a much less familiar meaning-based form of sociolinguistic analysis, the two strands unified by the study of interaction in social networks.

Gumperz's ideas thus describe a whole circle: professional network ties have specific kinds of sociolinguistic consequences, linguistic convergence with superficial diacritics of difference among them. However, friendship and kinship networks foster an exuberance of rich repertoires, with the development of subtle contextualization cues. When these cues are introduced into professional networks, they engender miscommunications, so generating the many minor tragedies of the interview situation, which can nevertheless influence individuals' life chances.

Space precludes adequate treatment of other of Gumperz's notions that are now part of the standard vocabulary of linguistics and sociolinguistics. Suffice it to say that he introduced or redefined notions like the speech community, repertoire, metaphorical switching, contextualization, linguistic convergence, interactional sociolinguistics, and many others.

Gumperz's role in establishing modern sociolinguistics was recognized by many awards. He was fellow of the American Academy of Arts and Sciences; distinguished fellow of the American Anthropological Association; life fellow of the Linguistic Society of America; a Guggenheim fellow; a visiting fellow at the Institute of Advanced Studies, Princeton; an overseas fellow at Churchill College, Cambridge University; and a fellow at the Center for Advanced Study in the Behavioral Sciences, Stanford University. He also served as the inaugural president of the International Pragmatics Association (1986-90), and an award was established in his name by the American
Educational Research Association. He was honored with a special session of the American Anthropological Association in his presence the December before his death and a resulting special issue of the Journal of Linguistic Anthropology (Jacquemet 2013).

Gumperz's legacy also resides in his training of students and colleagues, many of whom went on to be major figures in anthropological linguistics, the ethnography of communication, and sociolinguistics. He never tried to found a school closely based on a particular method or theory. Instead, he encouraged students to find their own way, giving them a tape recorder, encouraging exploratory fieldwork, showing them how to transcribe and analyze, and receiving half-baked ideas with an enthusiasm that transformed them. This open-ended, generous mode of instruction and collaboration means that his contribution is diffusely represented across a wide band of researchers both within and outside of academia (see, e.g., Auer and Roberts 2011). In addition, he was an important conduit of ideas between Europe and the United States. His projects with local collaborators on both sides of the Atlantic led to a flourishing of work on language use, especially in the U.K. and Germany. Through the various aspects of his work, John Gumperz played a key role in establishing the study of language use in its social context over a period of half a century.

\section{NOTE}

1. See Paulston and Tucker 1997 for the history of the early foundation of sociolinguistics, wherein Gumperz's central role is evident. Sources on Gumperz's early career include the following: Dil 1971; Gumperz 1997; Gumperz and Cook-Gumperz 2013; and Murray 1992. I am grateful for comments and corrections from Dan Slobin, Sue Ervin-Tripp, Bill Hanks, and other colleagues and to Sydel Silverman for skillful editing. Further biographical notes will be found on the Berkeley website at http://www.lib.berkeley. edu/ANTH/emeritus/gumperz, along with a complete bibliography of Gumperz's work.

Stephen C. Levinson Language and Cognition Department, Max Planck Institute for Psycholinguistics, 6500 AH Nijmegen, The Netherlands; Stephen.Levinson@mpi.nI

\section{REFERENCES CITED}

Auer, Peter, and Celia Roberts, eds.

2011 Special issue, "In Honor of John Gumperz," Text and Talk 31(4).

Bateson, Gregory

1956 The Message “This Is Play.” In Group Processes: Transactions of the Second Conference. Bertram Schaffner, ed. Pp. 145242. New York: Josiah Macy Jr. Foundation. 
Blom, Jan-Petter, and John J. Gumperz

1972 Social Meaning in Linguistic Structures: Code Switching in Northern Norway. In Directions in Sociolinguistics: The Ethnography of Communication. John J. Gumperz and Dell Hymes, eds. Pp. 407-434. New York: Holt, Rinehart, and Winston.

Bloomfield, Leonard

1933 Language. New York: Henry Holt.

Dil, Anton, ed.

1971 Language in Social Groups: Essays by John Gumperz. Stanford: Stanford University Press.

Ferguson, Charles A., and John J. Gumperz, eds.

1960 Linguistic Diversity in South Asia: Studies in Regional, Social and Functional Variation. International Journal of American Linguistics 26(3): part 3, vii-18.

Gumperz, John J.

1958 Dialect Differences and Social Stratification in a North Indian

Village. American Anthropologist 60(4):668-681.

1982a Discourse Strategies. Cambridge: Cambridge University Press.

1997 Some Comments on the Origin and Development of Sociolinguistics: Conversation with John Gumperz. In The Early Days of Sociolinguistics: Memories and Reflections. Christina Bratt Paulston and G. Richard Tucker, eds. Pp. 113-120. Dallas: The Summer Institute of Linguistics.

2001 Interactional Sociolinguistics: A Personal Perspective. In The Handbook of Discourse Analysis. Deborah Schiffrin, Deborah Tannen, and Heidi E. Hamilton, eds. Pp. 215-228. Malden, MA: Blackwell.

Gumperz, John J., ed.

1982b Language and Social Identity. Cambridge: Cambridge University Press.

Gumperz, John J., and Jenny Cook-Gumperz

2008 Studying Language, Culture, and Society: Sociolinguistics or Linguistic Anthropology? Journal of Sociolinguistics 12(4):532-545.

2013 Concluding Remarks. Special issue, "In Honor of John J. Gumperz," Journal of Linguistic Anthropology 23(3): 213-214.
Gumperz, John J., and Dell Hymes, eds.

1964 Special issue, “The Ethnography of Communication,” American Anthropologist 66(6[2]).

1972 Directions in Sociolinguistics: The Ethnography of Communication. New York: Holt, Rinehart and Winston.

Gumperz, John J., T. C. Jupp, and Celia Roberts

1979 Crosstalk: A Study of Cross-Cultural Communication, Background Material and Notes to Accompany the BBC Film. London: BBC.

Gumperz, John J., and Stephen C. Levinson, eds.

1996 Rethinking Linguistic Relativity. Studies in the Social and Cultural Foundations of Language series. Cambridge: Cambridge University Press.

Gumperz, John J., and Robert Wilson

1971 Convergence and Creolization: A Case from the Indo-Aryan/Dravidian Border in India. In Pidginization and Creolization of Languages. Dell Hymes, ed. Pp. 151-167. Cambridge: Cambridge University Press.

Jacquemet, Marco, ed.

2013 Special issue, "In Honor of John J. Gumperz," Journal of Linguistic Anthropology, 23(3).

Levinson, Stephen C.

1997 Contextualizing “Contextualization Cues.” In Discussing Communication Analysis 1. John J. Gumperz, Susan Eerdmans, Carlos Prevignano, and Paul J. Thibault, eds. Pp. 24-30. Lausanne: Beta.

Murray, Stephen O.

1992 North American Contributions to the History of Linguistics. Journal of Linguistic Anthropology 2(2): 233-234.

Paulston, Christina Bratt, and G. Richard Tucker, eds.

1997 The Early Days of Sociolinguistics: Memories and Reflections. Publications in Sociolinguistics, 2. Dallas: Summer Institute of Linguistics.

Twitchin, John, prod., and Fiona Thompson, dir.

1979 Crosstalk. 30 min. Series: Multi-Racial Britain. London: BBC Education. 